\title{
Konflikten om \\ Nordkoreas atomvåben: Et lærestykke i fejlslagen afskrækkelse
}

\section{Af Liselotte Odgaard}

Afholdelsen af de 23. olympiske vinterlege i PyeongChang i Sydkorea fra den 9. til den 25. februar 2018 og de paralympiske vinterlege fra den 9. til 18. marts skulle vise sig at være en enestående mulighed for at vende den højspændte situation på den koreanske halvø fra konfrontation og risiko for militær magtanvendelse over mod dialog med henblik på en varig løsning på konflikten om Nordkoreas atomvåben.

Med OL som undskyldning kunne Sydkoreas præsident Moon Jae-in forfølge sin ambition om at genoplive solskinspolitikken, som blev ført fra 1998 til 2008. Denne politik betoner samarbejde og dialog i den ellers dybfrosne relation mellem de to lande. Sydkorea og Nordkorea blev oprindeligt delt i to ved den 38 . breddegrad af de to sejrherrer, USA og Sovjetunionen, efter Anden Verdenskrig. Kort tid efter, i 1950, udbrød Korea-krigen med Nordkoreas invasion af Sydkorea. Den 27. juli 1953 forblev de to Koreaer delt med en våbenhvileaftale, der ikke var endelig og dermed ikke permanent afsluttede Korea-krigen.

Forsøget på ved OL i 2018 at slå ind på en samarbejdsorienteret linje med Nordkorea har imidlertid alle odds imod sig. Selvom annonceringen af et topmøde mellem Nordkoreas leder Kim Jong-un og USA's præsident Donald Trump (topmødet fandt sted 12 . juni 2018, red.) øgede forhåbningerne om, at der endelig kan findes en ordning, der fjerner atomvåben fra den koreanske halvø og skaber stabilitet, er det fortsat meget tvivlsomt, om der kommer særlig meget ud af dette forsøg på at skabe mere fredelige relationer mellem gamle fjender. 
De dårlige odds for en varig løsningsmodel skyldes, at de mange stater med aktier i den koreanske halvøs fremtid ikke er enige om, hvilken vej man skal gå. Det lægger en betydelig dæmper på forventningerne til, hvad der kan komme ud af den igangværende dialog.

\section{Ud over atomvåben besidder Nordkorea et af verdens største lagre af kemiske våben og er en betydelig konventionel militær magt.}

\section{Nordkoreas atomvåbenprogram} Nordkorea påbegyndte et atomvåbenprogram helt tilbage i 1980 'erne.
I perioden 1994 til 2002 enedes USA og Nordkorea om nedlukning af Nordkoreas atomvåbenprogram mod, at USA bistod Nordkorea med et fredeligt atomenergiprogram. Ingen af parterne overholdt imidlertid aftalen, og i 2003 trak Nordkorea sig ude af Aftalen om Ikke-Spredning af Masseødelæggelsesvåben. I 2006 påbegyndte Nordkorea atomprøvesprængninger, og FN's sikkerhedsråd indledte sit mangeårige sanktionsregime mod Nordkorea.

Sanktionerne har imidlertid ikke haft nogen påviselig indflydelse på Nordkoreas vilje til at indstille sit atomvåbenprogram. Tværtimod har Nordkorea i de sidste par år optrappet bestræbelserne på at kunne ramme

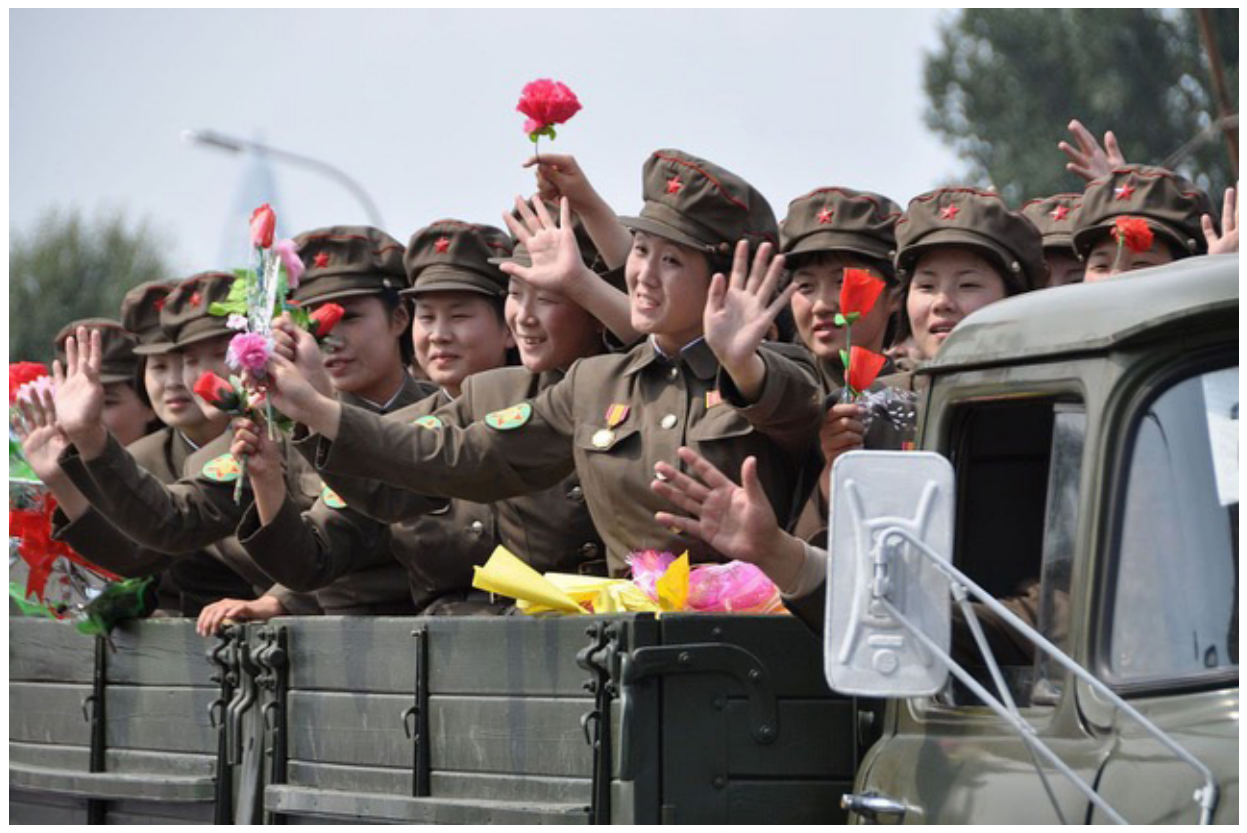

FOTO: Uri Tours via WIKIMEDIA commons

Nordkorea: Kvindelige soldater i militærparade, 2013 
USA med et interkontinentalt ballistisk missil og dermed udgøre en direkte trussel mod det amerikanske fastland. Ud over atomvåben besidder Nordkorea et af verdens største lagre af kemiske våben og er en betydelig konventionel militær magt. Man regner med, at Nordkorea råder over 70 ubåde, 4.300 kampvogne, 250 amfibiefartøjer, $1.300 \mathrm{fly}$, og meget mere.

\section{Konflikten mellem Nordkorea og USA}

Nordkorea koncentrerer sine ressourcer om at være en stærk militær magt, fordi regimet er ude i en overlevelseskamp i forhold til USA. Forårets ændringer i den amerikanske administration vil kun øge Pyongyangs mistillid til sikkerhedsgarantier fra amerikansk side.
Korea-konflikten. Ikke desto mindre er det næppe et persongalleri, der får Nordkorea til at gå til forårets møder med Sydkorea og USA om dets atomvåbenprogram med den store vilje til at afhænde de atomvåben, der beskytter Pyongyang mod et amerikansk militært indgreb, der med stor sandsynlighed vil føre til regimets kollaps.

Det er netop den overbevisende trussel fra USA, om at stormagten vil regimet i Nordkorea til livs, der betyder, at USA's trusler og konfrontatoriske politik mod Pyongyang er slået fejl. USA's konfrontation med Nordkorea er som Davids kamp mod Goliath i den forstand, at USA har overbevist Pyongyang om, at man vil regimet til livs, koste hvad det vil.

Det er den kalkulation, der får Nordkoreas ledelse til at holde fast $\mathrm{i}$ atomvåbenprogrammet, for at det ikke skal gå Kim Jong-un, som det er gået andre regimer, som USA har udnævint
Trumps fyring af Rex Tillerson som udenrigsminister og H.R. McMaster som national sikkerhedsrådgiver til fordel for henholdsvis Mike Pompeo og John Bolton, begge kendt som høge uden den store vilje til at komme det nordkoreanske regime i møde. Bolton har ved flere lejligheder argumenteret for regimeforandring i Nordkorea, om nødvendigt med militære midler.

Pompeo og Bolton vil som alle andre være bundet på hænder og fødder af de internationale bindinger på USA's handlefrihed, der følger af andre stormagters engagement $i$ til pariaer - fx Iraks Saddam Hussein og Libyens Muammar al-Gaddafi. Og det er USA's trussel mod regimet i Pyongyang, der gør Nordkoreas trussel om at svare igen på et amerikansk angreb med massiv magtanvendelse mod nabolande som Sydkorea og Japan samt amerikanske baser i nærområdet troværdig.

Chancerne, for at Nordkorea vil skille sig af med de våben, der angiveligt har sikret dets overlevelse, er ikke store. Derfor vil Nordkorea forventeligt maksimalt gå med til at fryse sin atomvåbenkapabilitet ned på en måde, 
der tillader Nordkorea at genopfinde den igen ret hurtigt, hvis de sikkerhedsgarantier, USA måtte stille i forbindelse med en eventuel aftale, ikke opleves som troværdige af Pyongyang.

\section{Sydkoreas håb om at genstarte solskinspolitikken kan vise sig at få vanskelige kår, hvis forårets møder ender uden aftaler om Nordkoreas atomvåben.}

En aftale, der kun tilsyneladende fjerner atomvåben fra den koreanske halvø, er der ikke de store chancer for, at USA vil gå med til. I hvert fald vil det være en meget stor kamel at sluge for en amerikansk administration bestående af mange høge med en erklæret hård linje over for Nordkorea og uden den store velvilje over for et Iran, der fik en aftale om nedfrysning med USA under præsident Obama, og som ikke var lige så langt i sin udvikling af atomvåben, som Nordkorea er.

En Iran-lignende aftale mellem Nordkorea og USA synes derfor ikke særlig sandsynlig, selv om lande som Sydkorea, Kina og Rusland formentlig vil hilse denne løsning velkommen. Hvis Nordkorea som modydelse kræver Sydkoreas missilforsvar fjernet, vil det også være en udmærket løsning for disse lande.

Så det er USA, der mest sandsynligt sætter en stopper for den type aftale. Men der er næppe muligheder for meget andet, for Nordkoreas modkrav til gengæld for en mere vidtgående atomvåbenaftale vil formentlig kræve så betydelig en nedrustning fra USA's og dets allieredes side, at det ikke er et særligt realistisk scenario.

USA har allerede slugt en meget stor kamel ved at annoncere topm $\varnothing$ det mellem Trump og Kim Jong-un. Hermed har USA nemlig accepteret at forhandle med et atombevæbnet Nordkorea, og det strider mod tidligere krav om, at Pyongyang skulle udvise håndgribelige tegn på vilje til afnuklearisering, hvis Washington skulle sætte sig til forhandlingsbordet. Nordkorea har til gengæld indstillet sine missiltests og atomprøvesprængninger frem til topmødet og accepterer, at USA og Sydkorea genoptager deres fælles militære øvelser på den koreanske halvø i en neddæmpet form inden topmødet.

Det er derfor ikke noget særlig stort vindue for en aftale, som de to parter synes at stå med forud for det planlagte topmøde. Det kan derfor have lange udsigter, før Nordkorea kan rette fokus og ressourcer mod meget andet end deres militære formåen. Det betyder så også, at det kan vare længe, før Nordkorea kan påbegynde sociale og økonomiske reformer, der kan bringe dem ind under de internationale økonomiske strukturer, som sikrer vækst og velstand. Det skyldes, at sådanne reformer kræver åbenhed, og det er direkte i modstrid med nødvendigheden af lukkethed for at bevare Nordkoreas atomprograms omfang, formåen og placering relativt ukendt for omverdenen.

Sydkoreas håb om at genstarte solskinspolitikken kan vise sig at få vanskelige kår, hvis forårets møder ender uden aftaler om Nordkoreas 
atomvåben. For i sidste ende er Seoul helt afhængig af USA's forsvarsvilje, så længe Nordkorea udgør en trussel mod Sydkorea. litet på hold, uden at Nordkorea giver $\mathrm{k} ø \mathrm{~b}$ på muligheden for at genopfinde sine atomvåben, hvis Pyongyang fortsat føler sig truet af USA.

For Kina er stabilitet

Når der har været rygter om, at Kina favoriserede en ny leder som fx Kim Jong-uns halvbror Kim Jong-nam, er de blevet slået ihjel af det nordkoreanske regime.

\section{Den kinesiske nøgle}

Kina er Nordkoreas livline. Dette er senest blevet understreget af, at Kinas leder Xi Jinping er den første statsleder, der mødes med Kim Jong-un. Xis dialog med Kim Jong-un vil givetvis sætte rammerne for, hvad Nordkorea kan tilbyde for at løse konflikten om landets atomvåben.

Trods den megen omtale af Kinas samarbejdsvilje i implementeringen af FN's sanktioner i den internationale presse har Kina ikke vist vilje til at implementere sanktionerne i et omfang, der kan føre til det nordkoreanske regimes kollaps. Og med Trumps startskud til en handelskrig med Kina i slutningen af marts, annonceringen af en lov, der tillader gensidige besøg mellem Taiwans og USA's embedsmænd, og et voksende antal operationer til støtte for, at Det Sydkinesiske Hav er internationalt farvand, hvor militære fartøjer har ret til at sejle inden for 12 sømil af klipperev besat af Kina, er Beijings vilje til at komme USA i møde i spørgsmålet om Nordkorea gående mod nul.

Samtalen mellem Xi og Kim Jongun vil derfor med stor sandsynlighed koncentrere sig om spørgsmålet om at sætte Nordkoreas atomvåbenkapabi- førsteprioritet, og staJong-uns regime bliver siddende. Regimets fald ville føre til helt uoverskuelige sikkerhedsproblemer for nabolandene på den koreanske halvø, da der ikke er noget alternativ til det siddende regime. Når der har været rygter om, at Kina favoriserede en ny leder som fx Kim Jong-uns halvbror Kim Jong-nam, er de blevet slået ihjel af det nordkoreanske regime. Derfor er man holdt op med at tale om alternativer til Kim Jong-un.

Selvom relationen mellem Kina og Nordkorea ikke er i top, så er regimet i Pyongyang at foretrække frem for et kollaps af de politiske strukturer eller en sammenlægning med Sydkorea under det amerikanske alliancesystem.

Kina vil have lige så lidt tillid som Nordkorea til sikkerhedsgarantier fra stration. Derfor er sandsynligheden stor for, at Kina støtter en Iran-lignende løsning, der tillader Nordkorea at genopfinde sine atomvåben kombineret med en afmontering af Sydkoreas missilforsvar. Seouls missilforsvar har hele tiden været en torn i øjet på Kina, der ser det som et middel til at svække Kinas evne til at svare igen på et atomangreb og ikke blot som et middel til at beskytte Sydkorea mod Nordkoreas atomvåben.

Indtil videre er USA gået ind på de betingelser for forhandlinger, som Kibilitet kræver, at Kim den nuværende amerikanske admini- 
na i samarbejde med Rusland har stillet. Først annoncerede Kina og Rusland, at forhandlinger mellem USA og Nordkorea om en løsning krævede, at USA og Sydkorea indstillede deres militære øvelser. Til gengæld ville Nordkorea indstille sine missiltests og atomprøvesprængninger. Det var disse betingelser USA gik ind på under OL. Hvis der ikke kom noget ud af samtalerne med Nordkorea, kunne man trække i land ved at henvise til, at øvelserne blot var indstillet for at få afviklet de olympiske lege i god ro og orden. Dernæst har USA accepteret at forhandle med et atombevæbnet Nordkorea, der endnu ikke har taget skridt til at afskaffe sine atomvåben. Også dette skridt er et knæfald for den kinesisk-russiske linje.

\section{Sydkoreas splittelse}

Kina står relativt stærkt forud for Kim Jong-uns møde med Sydkoreas præsident Moon Jae-in. Det skyldes, at Sydkorea i realiteten langt hen ad vejen støtter den kinesiske linje i spørgsmålet om, hvilken vej man skal gå for at løse konflikten på den koreanske halvø.

Nordkoreas deltagelse i de olympiske lege i Sydkorea demonstrerede tydeligt, at Sydkorea gerne vil samarbejde med det nordkoreanske regime og ligesom Kina ser diplomatiske midler som den eneste vej frem mod en attraktiv løsning. Sydkorea er dybt afhængig af USA's vilje til at forsvare landet mod Nordkorea, hvis der alligevel skulle udbryde krig, $\mathrm{fx}$ ved et uheld på grund af fejlslagen signalgivning. Det er derfor tvivlsomt, at Sydkorea kan gå længere i arbejdet for en løsning end USA's administration ønsker. Alligevel har Sydkorea valgt at udstille uenigheden med høgene i USA's administration, $\mathrm{fx}$ da de i fuld offentlighed henstillede, at USA accepterede at indstille deres fælles militære øvelser med henblik på at få Nordkorea i tale.

Den liberale sydkoreanske præsident Moon Jae-in ønsker sikkerhedsgarantier fra Nordkorea, og de sikkerhedsgarantier kan Sydkorea efter Seouls opfattelse kun få gennem tilnærmelser til og samarbejde med Pyongyang frem for med militær magt. Det samarbejde kan godt indledes med et atombevæbnet Nordkorea, fordi Seoul deler Kinas og Ruslands opfattelse, at Nordkorea kun vil bruge atomvåben som svar på et amerikansk militært indgreb.

På trods af det etniske fællesskab mellem Nord og Syd har landene været adskilt så længe, at de romantiske forestillinger om en genforening er ved at være uddøde til gengæld for en frygt for den enorme regning, som skal betales af Sydkorea ved en genforening.
Der er selvfølgelig stadig risiko for et uheld, men Sydkorea ser økonomisk, socialt og kulturelt samarbejde mellem Syd og Nord som den eneste farbare vej mod at genrejse Nordkoreas tillid til sine omgivelser så meget, at de ikke finder det nødvendigt at have atomvåben. Sydkorea har faciliteret direkte forhandlinger mellem Pyon- 
gyang og Washington i håbet om, at det kan genstarte samarbejdspolitikken mellem Nord og Syd fra 00'erne og lukke ned for de amerikanske trusler om et militært indgreb.

I modsætning til Sydkoreas officielle politik er store dele af befolkningen ikke interesseret $\mathrm{i}$ en genforening. Især har den unge del af befolkningen ingen lyst til at betale prisen for at blive genforenet med et land, der i økonomisk og social forstand er middelalderligt sammenlignet med Sydkorea, som mere minder om de vesteuropæiske lande i levestandard og uddannelsesniveau. På trods af det etniske fællesskab mellem Nord og Syd har landene været adskilt så længe, at de romantiske forestillinger om en genforening er ved at være uddøde til gengæld for en frygt for den enorme regning, som skal betales af Sydkorea ved en genforening.

Dertil kommer de sociale spændinger, der givetvis vil følge i kølvandet på en forening af folk, der i økonomisk og social forstand sandsynligvis vil blive opdelt $i$ et A-hold af veluddannede med $h ø j$ indtjening og indflydelse og et B-hold uden megen brugbar uddannelse i en moderne $ø$ konomi og med dertil hørende lave indtjeningsmuligheder.

Det var en vanskelig proces for Vest- og Østtyskland, men det er intet mod, hvad det vil være for Syd- og Nordkorea, der ligger meget længere fra hinanden i udviklingsniveau. Dette er endnu en tungtvejende grund til, at Sydkorea ønsker et samarbejde med regimet i Pyongyang og ikke støtter regimeforandring.
Unge sydkoreaneres manglende interesse i en genforening kom til udtryk under OL. Der var stor utilfredshed blandt de unge generationer med, at OL skulle shanghajes til politiske formål. Beslutningen om kort tid før OL at sætte sydkoreanere af det fælles kvindelige ishockeyhold til fordel for at få nordkoreanere til at spille med på holdet førte til massiv kritik. Der var ikke den store forståelse for, at års træning skulle ofres på et politisk alter $i$ en sportslig kontekst, der angiveligt netop bryster sig af at være apolitisk. For mange sydkoreanere var det helt forkert at prioritere en tilnærmelse til Nordkorea over sydkoreanske atleters medaljechancer. På hjemmebane har den meget populære sydkoreanske præsident derfor måttet lægge ryg til en hel del kritik af sin Nordkorea-politik. Ikke desto mindre har Moon Jaein fastholdt kursen rettet mod en genoplivning af solskinspolitikken.

\section{De perifere spillere}

Rusland har været en støtte for Kina under den seneste konflikt om Nordkoreas atomvåben. Rusland og Kina har i dag på en lang række områder fælles interesser i at imødegå USA's og dets allieredes politik i deres respektive nærområder.

Geografisk har de forskellige prioriteter. Asien-Stillehavsområdet står $\emptyset$ verst på Kinas dagsorden, mens Europa og Arktis er Ruslands førsteprioritet. Det har fået Beijing og Moskva til at etablere en arbejdsdeling, der betyder, at når Kina er udfordret i sit nærområde, bakker Rusland op om Kinas politiske linje til gengæld for, at 
Beijing spiller en lignende rolle som andenviolin, når det er Moskva, der er centrum for konflikt med USA og dets allierede.

På den nordkoreanske halvø har Kina og Rusland kørt et forbilledligt parløb, eksempelvis med fælles forslag til, hvordan USA og Nordkorea kunne bringes til forhandlingsbordet. Desuden har Rusland overtaget en del $\varnothing$ konomiske transaktioner med Nordkorea på grund af den tætte overvågning af, om Kina overholdt FN-sanktionerne. Det kinesisk-russiske parløb står i kontrast til de åbenlyse uenigheder mellem USA og dets allierede på den koreanske halvø og svækker USA's forhandlingsposition over for Nordkorea. med andre konflikter og ikke har råd til alt for meget uro mellem Beijing og Tokyo lige nu.

Japan har den indstilling, at Kina sidder med nøglen til at løse konflikten om Nordkoreas atomvåben. Japan ønsker ikke, at USA vælger en militær løsning, da Japan også ligger i skudlinjen, hvis Nordkorea svarer igen med massiv militær gengældelse. Men Japan er af den opfattelse, at et maksimalt pres på Kina for at standse økonomiske transaktioner med Nordkorea og overførsel af teknologi, der kan bruges til at fremstille masseødelæggelsesvåben, kan få Nordkorea til helt at opgive sine atomvåben.

Japan har intet til overs for regimet i Pyongyang og ser gerne regimeforandring gennemført, bare det ikke sker med

Med de uenigheder, der tegner sig mellem staterne med aktier i den koreanske halvøs fremtid, er det svært at tro på andre udgange end, at Nordkorea beholder sine atomvåben $i$ en eller anden form, uanset om de bliver pakket ned og gemt væk $i$ et bjerg, hvor det meste alligevel er i forvejen.

Japan er hardlineren i rækken af stater med interesser i den koreanske halvø. Japan har et historisk betinget dårligt forhold til Kina, som bunder $i$, at Japan med vestlige midler leverede dødsstødet til det kinesiske imperiums dominans i Asien i starten af det tyvende århundrede. På trods af at relationen for tiden er bedre end i mange år, er der næppe tale om en permanent forbedring. Dertil stikker mistilliden og naget for dybt. Der er tale om en forbedring, der hovedsagelig skyldes, at begge stater har travlt et militært indgreb. På denne baggrund har Tokyo opfordret Washington til at lægge en hårdere linje over for Beijing, end USA har været villig til i Nordkorea-spørgsmålet. Tokyo er USA's vigtigste allierede og har betydelig lydhørhed i Washington. Det kan gøre det endnu vanskeligere at nå frem til en løsning på Korea-konflikten, hvis det eneste, Nordkorea kan gå med til, er en nedfrysning af sine atomvåben.

\section{Den sandsynlige udgang}

Med de uenigheder, der tegner sig mellem staterne med aktier i den koreanske halvøs fremtid, er det svært at tro på andre udgange end, at Nordkorea beholder sine atomvåben i en 
eller anden form, uanset om de bliver pakket ned og gemt væk i et bjerg, hvor det meste alligevel er i forvejen, eller atomvåbnene forbliver som hidtil. En diplomatisk løsning er stadig en mulighed, men der er ikke mange, der tror på den, hvis Nordkorea insisterer på at beholde sine atomvåben.

Og en militær løsning er stadig usandsynlig. Uanset høgenes dominans i Washington er det stadig en løsning, der efter al sandsynlighed er forbundet med så store menneskelige og materielle omkostninger, at USA må forventes at vige uden om denne fremgangsmåde. På et eller andet tidspunkt får USA andet at tænke på, hvad enten det er handelskrigen, der begynder at have alvorlige konsekvenser for USA's økonomi, eller det er Taiwan-problematikken, der fører til alvorlig konflikt med Fastlandskina.

Det kan måske være den mest sandsynlige vej til større stabilitet og et lavere spændingsniveau på den koreanske halvø. 